\title{
Conservative treatment for Carpal Tunnel Syndrome caused by persistent median
}

\section{artery: a case report}

Tratamento conservador para síndrome do túnel do carpo causada por artéria mediana persistente: relato de caso

Tratamiento conservador para el síndrome del túnel carpiano causado por arteria mediana persistente: reporte de caso

Received: 09/21/2021 | Reviewed: 09/24/2021 | Accept: 09/26/2021| Published: 09/27/2021

Beatriz Pereira Vaz Tamiozzo

ORCID: https://orcid.org/0000-0002-8681-0674

Universidade de Vassouras, Brasil

E-mail: bvaz.tamiozzo@gmail.com

Eduardo Tavares Lima Trajano

ORCID: https://orcid.org/0000-0001-7809-7138 Universidade de Vassouras, Brasil

E-mail: eduardolimatrajano@hotmail.com

Marco Aurélio dos Santos Silva

ORCID: https://orcid.org/0000-0002-2400-6656 Universidade de Vassouras, Brasil

E-mail: santos-silvabiomec@hotmail.com

Larissa Alexsandra da Silva Neto Trajano ORCID: https://orcid.org/0000-0002-2600-9770

Universidade de Vassouras, Brasil

E-mail: larissa.alexsandra@hotmail.com

\begin{abstract}
Knowledge of a persistent median artery, defined as an anatomical vascular variation, is of clinical importance because it can be an unusual etiology of carpal tunnel syndrome. This report describes the case of a 42-year-old female patient with acute pain and paresthesia involving the volar aspect of the first, second, and third fingers of the left hand. The clinical manifestations pointed to compressive neuropathy of the median nerve, and diagnostic imaging showed anatomical vascular variation. Details were collected through interviews with the patient, and photographic records of imaging exams were thoroughly analyzed. This case study shows the importance of the identification and knowledge about anatomical variations considering that under specific pathological conditions, they can be a cause of clinical syndromes. Such knowledge is also important in the field of surgery for the prevention of iatrogenic injuries. Keywords: Anatomic variation; Carpal tunnel syndrome; Persistent median artery; Treatment; Case report.
\end{abstract}

\section{Resumo}

O conhecimento de uma artéria mediana persistente, definida como uma variação vascular anatômica, é de importância clínica porque pode ser uma etiologia incomum para a síndrome do túnel do carpo. Este relato descreve o caso de uma paciente de 42 anos com dor aguda e parestesia envolvendo a face volar do primeiro, segundo e terceiro dedos da mão esquerda. As manifestações clínicas apontaram para neuropatia compressiva do nervo mediano e o diagnóstico por imagem mostrou variação vascular anatômica. Os detalhes foram coletados por meio de entrevista com a paciente e os registros fotográficos dos exames de imagem foram minuciosamente analisados. Este estudo de caso mostra a importância da identificação e do conhecimento das variações anatômicas, visto que, em condições patológicas específicas, podem ser causa de síndromes clínicas. Esse conhecimento também é importante na área de cirurgia para a prevenção de lesões iatrogênicas.

Palavras-chave: Variação anatômica; Síndrome do túnel do carpo; Artéria mediana persistente; Tratamento; Relato de caso.

\section{Resumen}

El conocimiento de una arteria mediana persistente, definida como una variación vascular anatómica, es de importancia clínica porque puede ser una etiología poco común del síndrome del túnel carpiano. Este informe describe el caso de una paciente de 42 años con dolor agudo y parestesia que afectaba la cara volar del primer, segundo y tercer dedo de la mano izquierda. Las manifestaciones clínicas apuntaban a neuropatía compresiva del nervio mediano y el diagnóstico por imágenes mostró variación anatómica vascular. Los detalles se recogieron a través de una entrevista 
con el paciente y se analizaron cuidadosamente los registros fotográficos de los exámenes de imagen. Este caso de estudio muestra la importancia de identificar y conocer las variaciones anatómicas, ya que, en determinadas condiciones patológicas, pueden ser causa de síndromes clínicos. Este conocimiento también es importante en el campo de la cirugía para la prevención de lesiones iatrogénicas.

Palabras clave: Variación anatómica; Síndrome del túnel carpiano; Arteria mediana persistente; Tratamiento; Reporte de un caso.

\section{Introduction}

The median artery is a transient vessel that develops from the axial artery of the upper limb at the beginning of embryonic life (Alexander, Leal, \& Baptista, 2020). It follows the median nerve and can be a part of the structure of the superficial palmar arch. It is responsible for the blood supply of the hand in embryos (Haładaj, Wysiadecki, Dudkiewicz, Polguj, \& Topol, 2019). With the development of the radial and ulnar axial arteries, the median artery regresses and disappears during the post-fetal phase (Aragão, da Silva, Anunciação \& Reis, 2017).

A persistent median artery (PMA) is a rare anomaly (Aragão, da Silva, Anunciação \& Reis, 2017; Srivastava, Sharma, \& Pillay, 2015). It is an anatomical variation, which is defined as an embryonic vestige, and appears as a satellite vessel of the median nerve (Chim, 2016). The artery traverses the anterior aspect of the forearm, and in the distal region of this segment, it accompanies the flexor muscle tendons as contents of the carpal tunnel (Jain et al., 2020).

The origin and evolution of the median artery are variable, and it can arise from the radial artery, the ulnar artery, or more commonly, the anterior interosseous artery (Jain et al., 2020). The median artery is the dominant vessel for blood supply in the embryonic hand. When it has an increased caliber $(>3 \mathrm{~mm})$ in the presence of some pathological conditions including internal thrombus, aneurysm, and the formation of calcified plaques, it becomes an independent risk factor for carpal tunnel syndrome (CTS) (Chen, Chen, Hu, \& Jiang, 2017; Feintisch, Ayyala, \& Datiashvili, 2017). CTS is one of the most common pathologies of the hands (Wright \& Atkinson, 2019) and is characterized by compression of the median nerve in the wrist, causing pain, paresthesia, numbness, and weakness in the hand (Ono, Clapham, \& Chung, 2010; Wang, Buterbaugh, Kadow, Goitz, \& Fowler, 2018). This case report describes an unusual etiology of CTS and highlights magnetic resonance imaging as a diagnostic method to assist in the recognition of anatomical variations and conservative treatment as an alternative to surgical procedures.

\section{Methodology}

This study presents a case report that according to Yin (2015); Pereira et al. (2018) and Ludke and Andre (2013) is a methodology that focuses on a rare specific case and in which the phenomenon under study is detailed.

This is a qualitative study in which the patient sought private care to relieve pain in the region of the left wrist and hand, associated with a tingling sensation mainly affecting the fingertips. After the diagnosis of the rare case and after successful conservative treatment, the patient's case was reported. To this end, the patient signed a Free and Informed Consent Form. All procedures performed in this study adhered to ethical standards. This case was approved by the University of Vassouras Research Ethics Committee, Vassouras, Brazil (process number 4.670.438).

\section{Case Description}

A 42-year-old female patient complained of sudden onset of severe pain (visual analog scale score, 8) involving the region of the left wrist and hand, associated with a tingling sensation mainly affecting the fingertips. After the onset of pain symptoms, the patient used oral analgesics (Novalgine, 1g, 12/12 hours) and non-hormonal anti-inflammatory drugs (Nimesulide, $100 \mathrm{mg}, 8 / 8$ hours) continuously for 10 days. After 10 days following medical protocols, she sought medical care 
because of persistent pain. There was no correlation between the onset of symptoms and movements or repetitive actions. She had no comorbidities and denied alcoholism and smoking. There was no history of local trauma or surgery; rheumatological, oncological, or thyroid diseases; or muscle weakness.

The Phalen and Tinel tests showed positive results. The patient was instructed to maintain the use of oral analgesic medications, undergo cryotherapy, rest the joint, and undergo immobilization with an orthosis for a minimum period of 45 days. Stretching of the wrist, hand, and fingers was also performed according to medical guidelines. Ultrasound examination of the left wrist was requested due to a suspicion of compression syndrome of the median nerve at the level of the carpal tunnel.

Ultrasound examination without Doppler analysis of the left wrist showed enlargement of the median nerve, and a tubular structure between the nerve was identified, raising the possibility of an anatomical vascular variation. As there was no improvement in pain 30 days after treatment, magnetic resonance imaging of the left wrist was performed, which confirmed the presence of a PMA, with signs of thrombosis (Figure1).

Figure 1: (A) Axial T1-weighted magnetic resonance imaging with a proton density with fat suppression sequence showing a persistent median artery (white arrow). (B) Axial T1-weighted magnetic resonance imaging with a fat suppression sequence, without venous administration of paramagnetic contrast medium, showing a persistent median artery (white arrow); (C) after intravenous administration of a paramagnetic contrast medium, a persistent median artery, of increased caliber and with thrombosis, with only peripheral enhancement (white arrow) is observed.

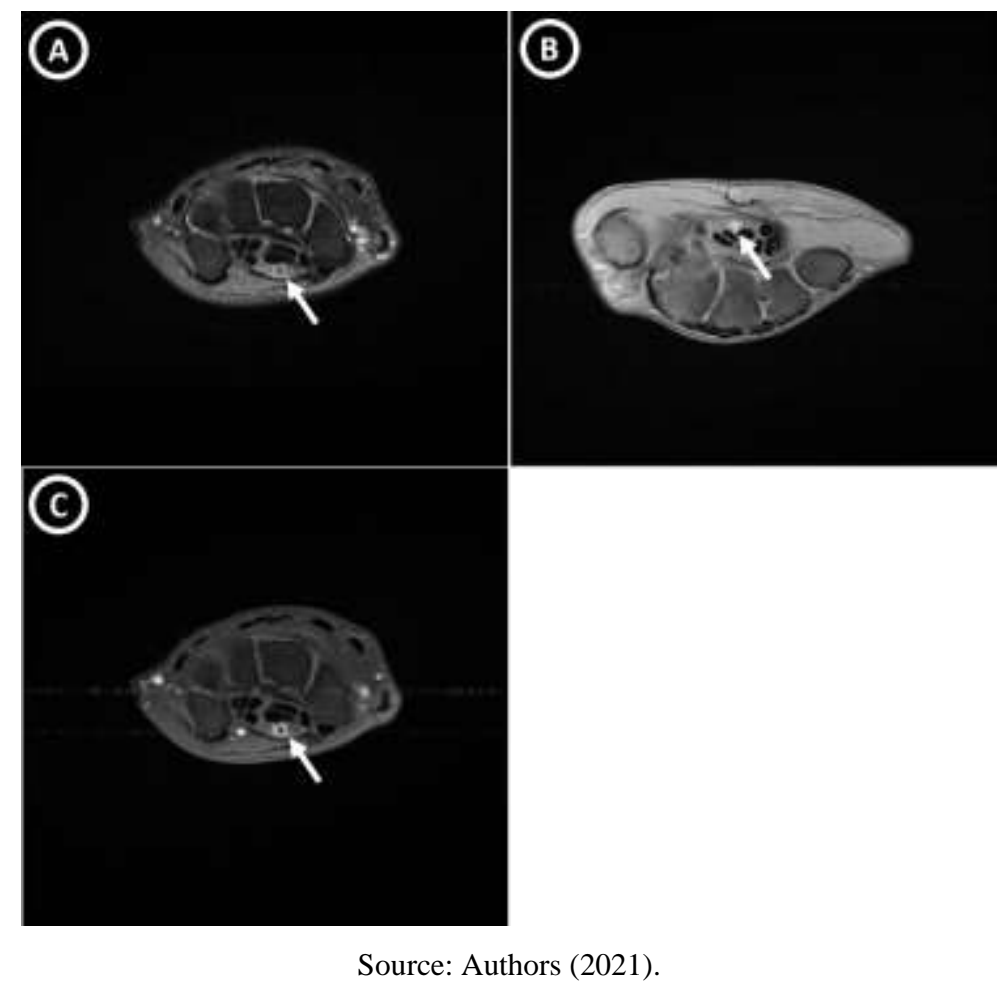

New treatment was performed using injectable Diprospan, with a dose of $2 \mathrm{ml}$ via deep intramuscular injection in a single dose, leading to a satisfactory improvement in the initial clinical condition (pain and paresthesia) in 15 days. Conservative treatment was concluded after 2 months, with adequate patient satisfaction and complete resolution of clinical symptoms; there was no need for surgical treatment for the decompression of the median nerve and the thrombotic event. The patient remains asymptomatic, with no recurrence of pain. The evolution of the treatment is shown in Figure 2. 
Figure 2: Treatment timeline from the patient admission, evolution, and discharge.

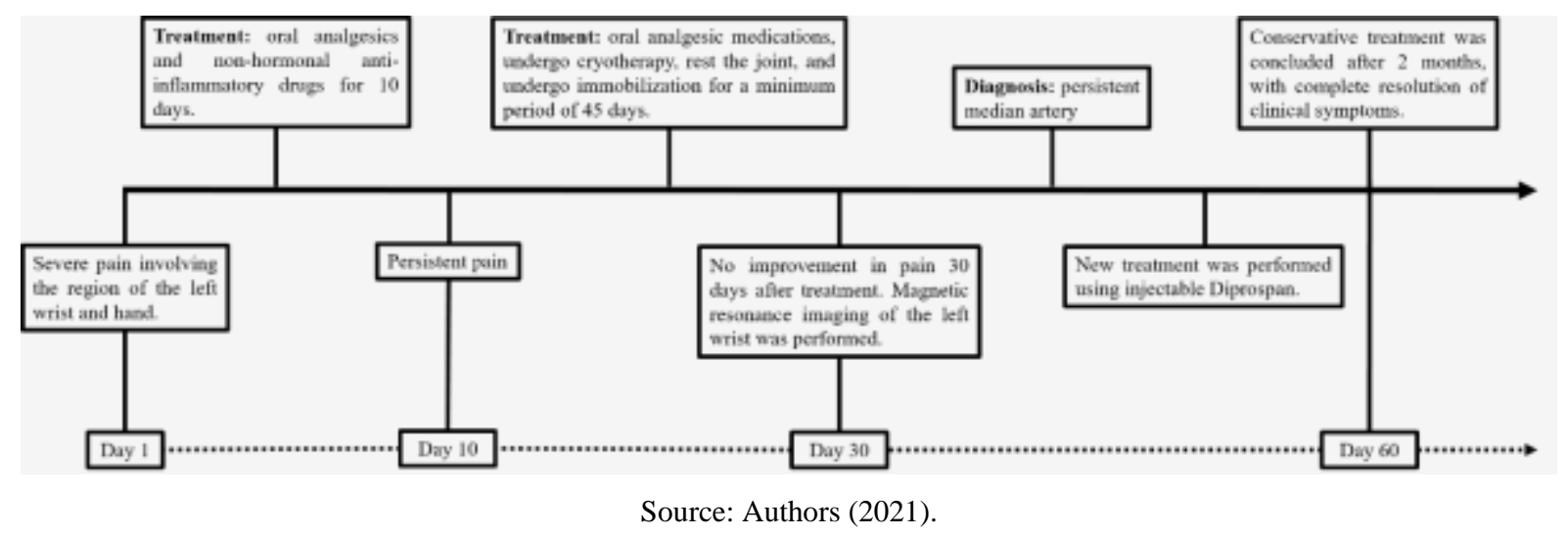

\section{Discussion}

Inflammatory changes in the tendons, nerves, and joint compartments, which are frequent causes of CTS, were ruled out. Thus, magnetic resonance imaging of the left wrist was requested, which surprisingly showed a PMA complicated with vascular thrombosis, establishing the etiology of CTS. A PMA with thrombosis causing CTS is uncommon (Jain et al., 2020). Clinically, a PMA can show manifestations when it dilates, when it is thrombosed (Akgun, Ertan, \& Ulus, 2017), or when it calcifies (Singla, Kaur, \& Dhiraj, 2012). Thrombosis of a PMA with subsequent development of acute CTS has been previously described (Vag, Koch, Waldt, \& Wörtler, 2012). In the present case, the PMA was characterized by arterial thrombosis.

Current studies have indicated that magnetic resonance imaging is an important auxiliary tool for identifying unusual causes of CTS (Chen, Chen, Hu, \& Jiang, 2017) and can be used to detect rare pathological causes of CTS (Jeon, Lee, \& Yang, 2020); this is important for differential diagnosis in cases involving ambiguous symptoms (Ibrahim, Khan, Goddard, \& Smitham, 2012). Magnetic resonance imaging has already been used for diagnosing thrombosis of a PMA with subsequent development of acute CTS (Vag, Koch, Waldt, \& Wörtler, 2012).

The existence of this vascular variant can contribute to varying complications, such as the pronator teres syndrome, compression of the median nerve, and compression of the anterior interosseous nerve (Potu et al., 2011). Recognizing anatomical variations in the arterial supply of the hand, including those of the superficial palmar arch, is necessary for performing safe and successful surgical procedures in the wrist and hand (Chim, 2016).

The reported case involved a vascular anatomical variation that presented as an unusual etiology of CTS; such variations are not always recognized but can play an important role in the appearance of clinical symptoms of a common pain syndrome in medical practice. usually, CTS is diagnosed based on clinical history and physical examination findings (wang, buterbaugh, kadow, goitz, \& fowler, 2018). However, in some cases, there is a need for diagnostic imaging methods for ensuring correct treatment and reduction of morbidity being able to solve the problem without the need for surgery.

\section{Conclusion}

In conclusion, PMA is an unusual etiology that can cause CTS. Magnetic resonance imaging is an important image exam for the recognition of this anatomical variation. The recognition of PMA is important to avoid misdiagnosis and delays in treatment and conservative treatment can be performed as an alternative with positive results in some cases.

Although the treatment offered to the patient had been successful, future research with a larger sample is important to assess whether conservative treatment will keep other asymptomatic patients without pain 


\section{References}

Akgun, A. S., Ertan, G., Ulus, S. (2017). Acute carpal tunnel syndrome caused by thrombosed persistent median artery associated with bifurcated median nerve in a pregnant woman. BMJ Case Rep., 2017, bcr2017221446.

Alexander, J. G., Leal, M. C., Baptista, J. D. S. (2020). Persistent median artery inside the carpal tunnel: description and surgical implications. Autops Case Rep., 10(4), e2020209.

Aragão, J. A., da Silva, A. C., Anunciação, C. B., \& Reis, F. P. (2017). Median artery of the forearm in human fetuses in northeastern Brazil: anatomical study and review of the literature. Anat Sci Int., 92(1), 107-111.

Chen, L., Chen, J., Hu, B., \& Jiang, L. X. (2017). Sonographic Findings of the Bifid Median Nerve and Persistent Median Artery in Carpal Tunnel: A Preliminary Study in Chinese Individuals. Clinics (Sao Paulo).,72(6), 358-362.

Chim, H. W. (2016). Persistent Median Artery Crossing and Continuing Distally as Ulnar Artery: Case Report. J Hand Surg Am., 41, e71-e72.

Feintisch, A. M., Ayyala, H. S., Datiashvili, R. (2017). An Anatomic Variant of Persistent Median Artery in Association with Carpal Tunnel Syndrome: Case Report and Review of the Literature. J Hand Surg Asian Pac Vol., 22(4), 523-525.

Haładaj, R., Wysiadecki, G., Dudkiewicz, Z., Polguj, M., Topol, M. (2019). Persistent Median Artery as an Unusual Finding in the Carpal Tunnel: Its Contribution to the Blood Supply of the Hand and Clinical Significance. Med Sci Monit., 25, 32-39.

Ibrahim, I., Khan, W. S., Goddard, N., \& Smitham, P. (2012). Carpal tunnel syndrome: a review of the recent literature. Open Orthop J., 6, 69-76.

Jain, R. D., Bathala, L., Anuradha, H. K., Kale, S. K., Pujar, G. S., Mehndiratta, M. M., \& Visser, L. H. (2020). A rare cause of median neuropathy at the carpal tunnel: Thrombosis of the persistent median artery. Indian J Radiol Imaging., 30(2), 229-232.

Jeon, S. Y., Lee, K., \& Yang, W. J. (2020). Carpal tunnel syndrome caused by thrombosed persistent median artery - A case report. Anesth Pain Med (Seoul)., 15(2), 193-198.

Ludke, M. \& Andre, M. E. D. A. (2013). Pesquisas em educação: uma abordagem qualitativa. E.P.U.

Ono, S., Clapham, P. J., \& Chung, K. C. (2010). Optimal management of carpal tunnel syndrome. Int J Gen Med., 3, $255-261$.

Pereira, A. S. et al. (2018). Metodologia da pesquisa científica. UFSM. https://repositorio.ufsm.br/bitstream/handle/1/15824/Lic_Computacao_MetodologiaPesquisa Cientifica.pdf?sequence $=1$.

Potu, B. K., Ray, B., Pai, S. R., Bhat, K. M., Pulakunta, T., Sarda, R., \& Mishra, S. (2011). A preliminary survey of the median artery in human cadavers of South Indian origin. Bratisl Lek Listy.,112(5), 292-295.

Singla, R. K., Kaur, N., Dhiraj, G. S. (2012). Prevalence of the persistant median artery. J Clin Diagn Res., 6(9), $1454-1457$.

Srivastava, A., Sharma, P., Pillay, S. (2015). Persistent median artery thrombosis: A rare cause of carpal tunnel syndrome. Australas $J$ Ultrasound Med., 18(2), $82-85$.

Vag, T., Koch, M., Waldt, S., \& Wörtler, K. (2012) Acute carpal tunnel syndrome from dissected and thrombosed persistent median artery diagnosed at magnetic resonance imaging. Rofo., 184(9), 829-30.

Wang, W. L., Buterbaugh, K., Kadow, T. R., Goitz, R. J., \& Fowler, J. R. (2018). A Prospective Comparison of Diagnostic Tools for the Diagnosis of Carpal Tunnel Syndrome. J Hand Surg Am., 43(9), 833-836.

Wright, A. R., \& Atkinson, R. E. (2019). Carpal Tunnel Syndrome: An Update for the Primary Care Physician. Hawaii J Health Soc Welf., 78(11 Suppl 2), 610 .

Yin, R. K. (2015). O estudo de caso. Bookman. 